\title{
大人との交渉を通じた重度精神遅滞児の 前言語的要求伝達の改善
}

\begin{abstract}
大 井学
9 歳の重度精神遅滞児 1 名の前言語的要求伝達についての大人との自然な交渉による指導 が、身ぶりと視線の協応、指示身ぶりの使用、明確化要請に対する身ぶり変更の 3 つの技能 に及ほす効果を検討した。指導は(1)大人を運動に誘う場面で子供の合掌を大人が模倣、(2)手 の届く範囲にある事物を大人と使おうとする場面で、合掌に対して物を吅く身ぶりのモデル を提供し、子供が物を吒くと大人がそれを模倣、(3)離れた所にある事物を大人と使おうとす る場面、退室の認可を求める場面で、合掌に対して事物や出口をさす到達のモデルを提供し、 子供が到達を使うと大人がそれを模倣、という順で実施した。子供は大人を見ながら合掌し、 事物や場所を大人を見ながら叮きや到達で示し、質問に対して、合掌を吒き、到達へと変更 するようになった。大人との交涉機会が之しいために伝達技能が制限されていた可能性があ る。重度遅滞児との交涉の成立と維持に身ぶりの模倣が有効であることが示唆された。
\end{abstract}

キー・ワード：重度精神遅滞 前言語的伝達 身ぶり

\section{I 。はじめに}

重度精神遅滞児の前言語的伝達にはいくつかの制約 がある。伝達の形式については子供に特異な非慣習的 身ぶりや、手を引くなどの直接的な身ぶりから、渡す、 差し出すなどの慣習的な身ぶりへ、さらに指さしなど の指示身ぶりへの移行が容易ではないという問題があ $3^{10)}$ 。伝達の語用論的な側面では、まず叙述的な伝達行 為が命令的な伝達行為に比べ少なく ${ }^{10)}$ 、談話行為につ いては応答に比べ開始が少ない199、渡すなどの接触身 ぶりしか持たない者は、聞き手の誤解や会話の行き詰 まりが起きた場合に、表現をより明確にするなどの修 正（repair）が乏しいという問題 ${ }^{11}$ がある。

身ぶりや音声にともなう視線についての研究はほと んどないが、中軽度遅滞児を対象とする研究象14)によ ると、音声や身ぶりと視線との協応がみられないこと が明らかにされており、これは重度遅滞児にもあては まるとみなしてよい。Wooton (198921) は 1 名の重度 遅滞のダウン症児において音声と視線が協応していな いことを見いだしている。

これらは認知能力の制約によるとみなされている が、他方で遅滞児は同一認知水準の非障害児に比べ伝 達技能が劣るという知見も多い ${ }^{18)}$ 。Labato, Barrera,

金沢大学教育学部 and Feldman ${ }^{10)}$ の結果では指さしや差しだしが感覚 運動の第 5 段階以上でないとみられないが、同時にこ れらの子供で大人の注意を得ないまま物を指すという ようなより低い段階の伝達行為が多くみられる。こう した認知と伝達のずれが何を意味するのかはまだ明ら かではないが、「一定の問題解決能力（道具使用の因果 性理解）を持ちながら、それを対人的な文脈の中で伝 達手段として用いていく能力 (大人使用の因果性理解) の未発達」(4) という可能性がある。この仮定に立てば 前言語期の重度児に対してどのように大人を使うか教 えるコミュニケーション中心のプログラムが求められ る。そこでは彼らにどのような伝達の環境を提供する のかということと共に、大人がどうかかわるかという ことが大きな問題となる。

ところが自然な場面での対人的な相互作用を通じた 言語指導をめざす、コミュニケーション・アプローチ あるいは語用論的アプローチによる研究は、初期統語 発話をもつ軽度遅滞児や言語発達遅滞児に限られ、重 度遅滞児を対象としたものがない。こうしたアプロー チは重度遅滞児についても有効と予想される。英語圈 ではコミュニケーション・アプローチによる重度遅滞 児むけのプログラムがいくつか提案されてい る4)17)20)。これらの目標は、意図的な伝達が見られない 子供に対しては、子供が何らかの信号をだすようにし、 
何らかの伝達がある場合には子供の特異的な表現をよ り適切な表現に変えるよう助ける。そのために子供か らの伝達を促すような環境の設定や、行動連鎖の中断 など伝達の促し、共同行為ルーティンの形成などの手 続きが示されているが、コミュニケーションの相手と しての大人の振る舞い方についての提案は乏しい。そ の背景として、前言語的な伝達に大人と子供とのコ ミュニケーションがどのように影響しているかがよく わかっていないという事情がある。

前言語的な伝達の発達に及ぼす大人とのコミュニ ケーションの影響については言語行為論に基づく Bruner $\left(1983^{3)}\right)$ の考えが参考となる。前言語的伝達は 初歩的な言語行為とみなすことができ、それに対し大 人は一方でモデルを提供しながら、前言語的な子供の 意図を明確にするよう助け、その表現を言語行為の条 件及び文化的な要請に沿うようにしていく。Bruner の 関心は意図をめぐる交渉を通じて身ぶりや音声がより 標準的な言語表現に入れ替っていく過程に限定されて いるが、その考えは前言語伝達自体の発達にもあては まると考えられる。Golinkoff $\left(1986^{5)}\right)$ は前言語段階 の子供と母親との間で伝達の失敗と修正 (repair)にか んする交涉が活発に行われており、子供が反復、追加、 新規の手段の使用など話題確立の方法を学んでいるこ とを報告した。木下 $\left(1987^{9)}\right)$ は子供の要求に対して大 人が「なに」と聞き返した場合、到達から指さしやチョ ウダイ身ぶりへの伝達行為の変更が 1 歳前からみられ 始め、1 歳前半では半数以上の子供が変更することを 示した。大井 $\left(1990^{15)}\right)$ は 10力月児と母親との間の要 求意図をめぐる交涉を示した。聞き手との交涉を成立 させるためには、話し手が自らの言語行為が聞き手の 実際的な行動に与える効果だけでなく、同時に聞き手 がどのように応答するのかについても注意しなければ ならない。逆に聞き手は話し手に有効にフィードバッ クされるような伝達行為を応答で用いなければならな い。言語的伝達では視線だけでなく、適切な休止をとつ て聞き手の発話を聞くことが重要であるが、身ぶり伝 達では聞き手への視線が重要である。障害のない子供 の前言語期における交渉の成立には視線をともなう身 ぶりや音声の出現が関連していると考えられる。交涉 が見られ始める 12 力頃までには、視線をともなわな い到達から視線をともなう到達や音声、さらに指さし へという移行がおきており2)、身ぶりや音声に合わせ て物と大人とを見比べる視線が確立されている11。

前言語期の重度遅滞児と母親との相互作用について は松尾・加藤 $\left(1989^{12)}\right)$ によって検討されている。しか
し意図をめぐる交涉にかんする研究はほとんどない。 後藤 $\left(1976^{6)}\right)$ は中度遅滞のダウン症児と母親とのあい だで言語関係が成立しないことが多く、特に非言語行 動を含まない場合に著しいことを示した。大井 ${ }^{16)}$ は要 求意図をめぐる交涉の失敗エピソードを語用論的に分 析し、重度遅滞児の要求身ぶりに対する大人の言語応 答が、要求の拒否や身ぶりの反復要請と受けとめられ たりすること、及び非言語応答が交涉の維持に有効で ある可能性を示唆した。交涉は聞き手が話し手の表現 を受信したことを聞き手に伝えることころから始ま る。コミュニケーション・アプローチの一つであるイ ンリアル7ではミラリングやモニタリングなど子供の 表現に対する大人の模倣が、受信を認め、表現のし直 しまたは明確化を間接的に要請し、話題を維持するな どの語用論的機能を担うことが指摘されている。重度 遅滞児との交涉を成立させそれを維持するには、大人 が身ぶりなど子供の非言語表現を模倣することが有効 と推測できる。

ここでは、要求伝達において身ぶりと視線との協応 が乏しく、指示の身ぶりを用いず、大人の明確化要請 に対して身ぶりを変更しない重度遅滞児 1名に、自然 に近い大人との交涉による指導を行う。子供の身ぶり を大人が模做するモニタリングが交渉の成立及び展開 に及㴗効果、交涉における大人からの指示身ぶりの モデルの提供が子供の伝達に及ぼす効果、及びそれら が身ぶりと視線の協応、身ぶりの変更に及ぼす効果に ついて検討する。

\section{II. 方 法}

\section{1. 対象児}

指導開始時 9 歳 5 力月の重度精神遅滞をもつ男子 (以下T児)。田研・田中ビネ一知能検查の精神年齢 1 歳 10 力月、 $\mathrm{IQ} 19$ 。絵画語菓検査の語菓年齢 2 歳 2 力月。 行動観察から評価された感覚運動知能の物の概念、目 的達成、因果性理解及び動作模做 ${ }^{13)}$ はすべて第 6 段階 である。弱視のため盲学校小学部に在籍、寄宿舎に入っ ている。右眼は光覚のみ、左眼は形態覚可能だが視力 は測定不能。精神年齢以上の幾何図形の視覚弁別が通 常の距離で可能。日常生活動作に問題はなく、上肢を 使った身ぶりはすぐに模倣できる。

伝達は身ぶりが支配的で、音声はあまり用いない。 身ぶりは主に事物、行為及び認可の要求に使い、叙述、 情報の機能はみられなかった。要求には所属集団内で 慣習化されたお辞儀をともなう合掌身ぶりを主に用 い、他に渡し、手引き、うなずきがみられた。この合 
大人との交涉を通じた重度精神遅滞児の前言語的要求伝達の改善

Table 1 指導の目標と手続き

\begin{tabular}{|c|c|c|c|}
\hline & 指 導 & 指 導 & 指 導 \\
\hline & $\begin{array}{l}\mathrm{S} 3-6 \\
\text { (S1,2はベースライン) }\end{array}$ & $\begin{array}{l}\text { 単一事物場面 (S 7-16) } \\
\text { 複数事物場面 ( S 17-24) }\end{array}$ & $\begin{array}{l}\text { 遠隔事物場面 (S 17-24) } \\
\text { 退室場面 (S 17-24) }\end{array}$ \\
\hline 標 & $\begin{array}{l}\text { 聞き手をみながら合掌す } \\
\text { る. }\end{array}$ & $\begin{array}{l}\text { 求める遊びに使う物を叨 } \\
\text { いて示す／大人を見なが } \\
\text { ら物を吒く. }\end{array}$ & $\begin{array}{l}2 \mathrm{~m} \text { 以上離れた物や場所 } \\
\text { を指さしまたは到達で示 } \\
\text { す/大人と物や場所を見 } \\
\text { 比べながら示す. }\end{array}$ \\
\hline 面 & $\begin{array}{l}\text { 大人とトランポリンで- } \\
\text { 緒に跳ぶ. 大人は途中で } \\
\text { 座り込む. 子供と大人は } \\
2 \mathrm{~m} \text { 離れて向き合ってい } \\
\text { る. }\end{array}$ & $\begin{array}{l}\text { 単一事物場面：大人が描 } \\
\text { いてくれる絵をみる／大 } \\
\text { 人と共に歌に合わせて手 } \\
\text { ぶりする. } \\
\text { 複数事物場面：描画の道 } \\
\text { 具、歌遊びの絵 } 5 \text { 枚、お } \\
\text { もちゃ } 2 \text { 種類のうち } 3 つ \\
\text { 以上が手の届く所に置か } \\
\text { れる. } \\
\text { 両場面とも大人と子供は } \\
\text { 物を㣣んで向き合う. }\end{array}$ & $\begin{array}{l}\text { 遠隔事物場面：指導II } \\
\text { 複数事物場面で用いた物 } \\
\text { を子供から } 2 \mathrm{~m} \text { 以上離し } \\
\text { て置く. 物は } 1 \mathrm{~m} \text { 間隔 } \\
\text { をあけて置く. 取ってき } \\
\text { た物で一緒に、また一人 } \\
\text { で遊ぶ. } \\
\text { 退室場面：すべての遊び } \\
\text { の終了後、子供は習慣的 } \\
\text { に別室に行く. } \\
\text { 両場面とも子供と大人は } \\
1 \mathrm{~m} \text { 離れて向き合う. }\end{array}$ \\
\hline 伝達 内容 & $\begin{array}{l}\text { 再度一緒にとぶように求 } \\
\text { める. }\end{array}$ & $\begin{array}{l}\text { 単一事物場面：新しい絵 } \\
\text { を描くよう求める／歌っ } \\
\text { てもらい一緒に手を動か } \\
\text { すよう求める. } \\
\text { 複数事物場面：大人に描 } \\
\text { 画、歌遊びのどれか } 1 つ \\
\text { をするように求めるか、 } \\
\text { または遊びたいおもちゃ } \\
\text { を } 1 \text { つ渡すように求め } \\
\text { る. }\end{array}$ & $\begin{array}{l}\text { 遠隔事物場面：大人にし } \\
\text { てほしい物、または自分 } \\
\text { がほしい物を、自分が } \\
\text { 立って取りに行くことを } \\
\text { 求める. } \\
\text { 退室場面：出口の方に向 } \\
\text { かって自分が歩いていく } \\
\text { ことを認めるよう求め } \\
\text { る. }\end{array}$ \\
\hline 大人の応答 & $\begin{array}{l}\text { 子供の合掌を大人が模倣 } \\
\text { する. } \\
\text { 少数の応答で拒否を示す } \\
\text { 腕組み身ぶりを行う. }\end{array}$ & $\begin{array}{l}\text { 単一事物場面：子供の合 } \\
\text { 掌に対して物を吒く/子 } \\
\text { 供が物を吒くと大人が模 } \\
\text { 倣する. } \\
\text { 複数事物場面：子供が物 } \\
\text { を渡そうとすると、物を } \\
\text { 吒く/子供が物を叮くと } \\
\text { 大人が模倣する. }\end{array}$ & $\begin{array}{l}\text { 子供の指さしまたは到達 } \\
\text { を大人が模倣する. }\end{array}$ \\
\hline
\end{tabular}

掌は数年前からみられた。退室の認可要求で到達様の 身ぶりがあったが、腕は屈曲し、掌は垂れ下がり出口 に向けられておらず、指示性がそしかった。な打「何々 はどれ」と問うと眼前の事物に手でふれる身ぶりがみ られたが、事物や行為の要求に扔いては物にふれる、 到達などの指示の身ぶりはみられなかった。このため 複数の事物から一つを選ぶ場合は、それをとって渡す しかしなかった。T児の手が届かない場合は大人が望
む物をとるまで合掌を繰り返すか、大人の手を引くか であった。感覚運動の第 6 段階に達しているのに指示 身ぶりがそしく、Labato,Barrera,and Feldman $\left(1981^{10}\right)$ の結果に照らすと伝達の技能は認知水準よりも低い。

合掌にともなう大人に対する視線は、身ぶりの前に だけみられた。これは視線接触をともなわず、要求の 充足者としての大人の存在を確めるものであった。聞 き手が $2 、 3 \mathrm{~m}$ 離れていたり背中を向けたりしていて 
Table 2 要求についてのT児と大人との交涉の例

\begin{tabular}{|c|c|c|c|}
\hline & 児 & & 大 \\
\hline \multicolumn{4}{|c|}{ 指導 I（Ｓ 3-2） 大人は跳ぶのをやめTの方をみる } \\
\hline 1 & 大人を見て、次に合掌 & \multicolumn{2}{|c|}{$2 「 お$ 願い」といいつつ合掌 } \\
\hline 3 & 大人を見て、次に合掌 & \multicolumn{2}{|c|}{$4 「 お$ 願い」といいつつ合掌 } \\
\hline 5 & 大人を見て、次に合掌 & \multicolumn{2}{|c|}{6 Tをみる } \\
\hline & 大人の手を取ろうとする & \multicolumn{2}{|c|}{8 動き始める } \\
\hline \multicolumn{4}{|c|}{ 指導 II ：単一事物場面（S 9-10）描画用具が両者の間にある } \\
\hline 1 & 大人を見ながら合掌 & 2 & 「これ」といいつつ用具をたたく \\
\hline 3 & 用具を見てたたく & \multicolumn{2}{|r|}{ 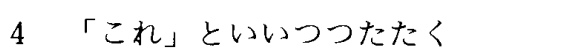 } \\
\hline 5 & 大人を見上げて合掌 & \multicolumn{2}{|c|}{$6 「 お$ 願い」といいつつ合掌 } \\
\hline 7 & 大人をみつつお辞儀 & \multicolumn{2}{|c|}{8 ペンを取る } \\
\hline \multicolumn{4}{|c|}{ 指導 II ：複数事物場面（S 9-3）絵を 5 枚並べ大人が「どれ」ときく } \\
\hline 1 & 大人を見、次に $1 つ の$ 絵を見てたたく & \multicolumn{2}{|c|}{2 同じ絵をたたく } \\
\hline 3 & 大人を見上げて合掌 & \multicolumn{2}{|c|}{4 合掌 } \\
\hline & 大人を見つつお辞儀 & \multicolumn{2}{|c|}{6 他の絵を片づける } \\
\hline \multicolumn{4}{|c|}{ 指導III：遠隔事物場面（S 19-2）描画用具、パズル、歌遊びの絵 } \\
\hline & 大人を見ながら合掌 & \multicolumn{2}{|c|}{2 「何」 } \\
\hline 3 & 描画用具を見て到達 & \multicolumn{2}{|c|}{$4 「$ 「れ」といいつつ指さす } \\
\hline & 物をみたままうなずき、立ち上がる & & \\
\hline \multicolumn{4}{|c|}{ 指導III：退室場面（S19-1） } \\
\hline & 大人を見ながら合掌 & 2 & 2 「どこいきたいの」 \\
\hline 3 & 出口見つつ到達 & \multicolumn{2}{|r|}{4 「テレビ」といいつつ出口を指さす } \\
\hline & 大人を見ながら合掌 & \multicolumn{2}{|c|}{6 合掌 } \\
\hline 7 & 出口へ行く & & \\
\hline
\end{tabular}

S 3-2 第 3 セッションの 2 番目の交涉エピソード

数字は夕ーンの順序を示す/大人㹥身ぶりの際に必ずT児をみる

も、接近したり正面に移動したりしなかった。身ぶり の後大人がすぐに要求を充足しないとあきらめること が多かった。大人の応答はすぐに要求を満たすか要求 内容の明確化を言語で求めるかのどちらかであった。 T児は「何ほしいの」等の明確化要求に対して合掌を 繰り返すのみで、それを変更しようとしなかった。 「じゃシーソーしょう」などのコメントに対しても合 掌を反復した。

\section{2. 指導及び研究の計画}

週 1 回、6力月間 24 回個別指導した。 1 セッションは 30 分から 1 時間程度。指導にあたった大人及び補助者 は、それまでにT児と 1 年以上週 2 回の割で寄宿舎で 接触してきた障害児教育専攻の学生 2 名である。放課 後に居室、体育館で指導した。指導は 3 つ、細かくは 5 つの場面に区別される。目標と手続き及び時期は Table 1 に示した。いずれの指導でもT肾からの要求 が生じる状況が設定され、それぞれの状況は同一指導 内、同一場面内では原則として変更せず、大人はT児 の伝達に応答し、原則として要求を充足するようにし
た。指導 I でまず交渉を成立させ、II、IIIで指示身ぶ りを使うことを教えるという順で進めるようにした。 要求場面の状況は T児と大人との間で既にルーティン 化しているものを部分的に手直しして設定した。指導 前は大人に従来通りのやり方で応答するよう求めた。 指導では大人に目標と手続きを著者が説明し、指導の 後に毎回ビデオ記録を検討して、応答のタイミング、 応答後の行動の展開について著者と協議した。

研究はそれぞれの指導と指導前との比較、及び指導 内の比較を行うょう計画された。S1、2 を指導 I のベー スラインとした。指導 II 単一事物場面は S1 から $\mathrm{S} 6$ ま でに起きた同じ場面で模倣しないものをそのべースラ インとした。複数事物場面は場面自体を指導 II 開始後 につけ加えた結果、吒きのモデル提供と模倣を除去す るのが不自然となり、指導前との比較ができない。指 導IIIはS7 から S16 までにおきた同じ場面をべースラ インとした。完全に統制されたABデザインはとって いないが、操作される変数が非常に単純で、目標との 密接な対応があり、充分にその効果を検証できる。ま 
Table 3 伝達行為のカテゴリと定義

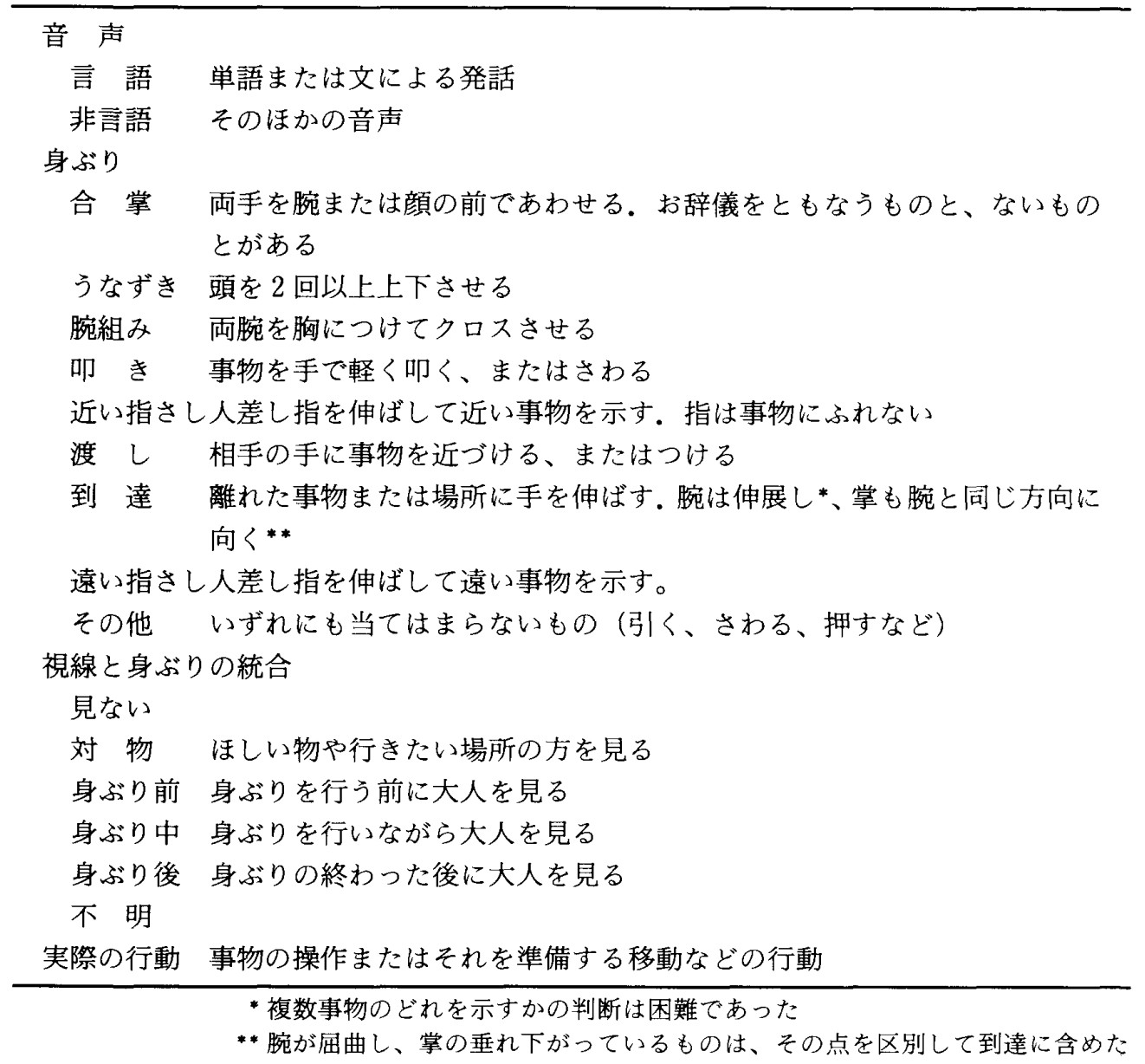

た取り上げられた問題について本指導以外のアプロー チは同時にはなされてはいない。指導期間中の学級担 任及び寄宿舎の寮母のT児の要求に対する応答を従前

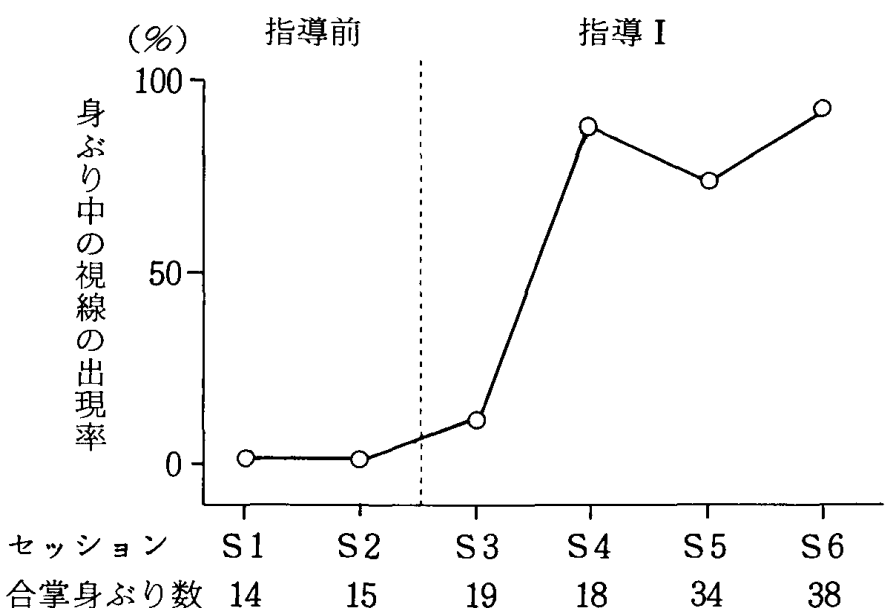

出現率 $=$ (身ぶり中の視線がある合掌身ぶり数/合掌身ぶり数) $\times 100$

Fig. 1 合掌身ぶり中の大人への視線の出現率の時期 的な変化
と変えないことが確認されている。すべての指導終了 後、類似場面における要求、指導に無関係であった活 動における要求及び及び指導にかかわらなかった大人 に対する要求について 3力月間観察した。

自然なコミュニケーションの維持に配慮したため、 大人の応答は完全に統制されてはいない。指導IIIの前 にはT児の到達身ぶりを模倣しないように計画した が、大人は自発的に模倣を行った。これをあえて除去 することを大人自身が不自然に感じたので、特に統制 しなかった。またセッション内の交涉エピソード (Table 2)の数も一定ではない。交渉エピソード数は、 指導 I が 9-32 (平均 19.25)、指導III単一事物場面が 5 -30 (平均 13.78)、指導 III複数事物場面が 8-18（平均 11.63)、指導III遠隔事物場面は 1-5(平均 2.88)、指導 III退室場面は 1-2（平均 1.20）である。

\section{3 . 分析と測度}

T児と大人との交涉を含む場面全体の行動をビデオ 記録し、指導に当たった大人と補助者が、T肾の要求 について大人との交渉がみられる䇢所のトランスクリ プトを著者と協議して作成した。音声、身ぶり、視線 
の各種伝達行為及び伝達に関連したその他の行動を含 め、T児と大人のターンの交代として文字転写した (Table 2)。各セッションは複数の交涉エピソードに 分割された。交涉エピソードの始まりは最初のT览の 要求表現とし、大人またはT览が実際的な行動に移る 所で終わりとした。それぞれの交涉エピソードに含ま れる両者の伝達行為を Table 3 の基準によって、トラ ンスクリプトとビデオ記録を照合しながら分類した。 3 つの指導の 5 つの場面についてそれぞれ 1 セッショ ンづつ、著者を含む 2 名が独立に分類した際の一致度 はいずれのカデゴリでも $90 \%$ 以上であった。残りは単 一の分類者によった。

指導 IについてはT児のすべての合掌における視線 の各カテゴリの出現割合をセッションごとに算出し た。指導IIについてはT肾の第一ターンにおける身ぶ りの各カテゴリの出現割合、そこで吒きがみられた場 合の視線の各カテゴリの出現割合をセッションごとに 算出した。指導IIIについてはエピソードが少ないので T览の第一、第二ターンに扔ける身ぶりの各カテゴリ の出現頻度、そこで到達がみられた時の視線の各カテ ゴリの出現頻度をセッションごとにカウントした。そ れぞれの指導前についても同様である。

\section{III. 結 果}

\section{指導 I}

指導 Iにおける T児のすべての合掌のうち大人が模 做したのは $60 \%$ 、腕組みによる応答が $17 \%$ であ。指
導前は合掌の模倣及び腕組み応答は無く、言語応答が 55\%、跳び始めるなどの実際の行動が $45 \%$ であった。 指導前のT览の合掌で身ぶり中の視線をともなうもの

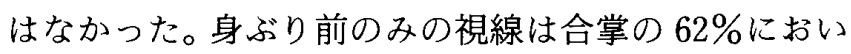
てみられた。身ぶりが終わった後にだけ大人を見るの は7\%であった。S4から身ぶり中の視線が急増して 70\%から 90\%の合掌でみられるようになり (Fig. 1)、 身ぶり前のみの視線はS4 以後はごくわずかになっ た。身ぶり後の視線は S3 の $30 \%$ の合掌で見られ、それ 以後は 1 回しかなかった。身ぶり中の視線をともなう 合掌では括辞儀が省略されていた。この視線は大人の 合掌まで保たれ、大人との視線接触を必ずともなった。 $\mathrm{S} 4$ 以後は大人が合掌を終えると T览は実際の行動に 移った。視線接触が成立したのは大人が原則としてT 児を注視していることによるが、T児から視線を合わ せようとする積極的な行動もみられた。大人がトラン ポリンを降りてT児から遠ざかると近づいてきて合掌 し、背を向けている場合には正面に回り込んで合掌し た。拒否を示す腕組は導入当初の S3 では大人の前で うろうろするだけであったが、S4にはそれを模倣し、 要求を中止して大人から離れるようになった。

\section{指導 II 単一事物場面}

指導前は合掌がほとんどで渡しが若干あった。指導 II の交渉エピソードにおけるT児の第一ターンの合掌 に対して大人が物を叮いてみせたのは $73 \%$ 、同じくT 児の第一ターンの吒きを大人が模倣したのは $61 \%$ 、指 導前はいずれもなかった。S7 から導入された大人の吒

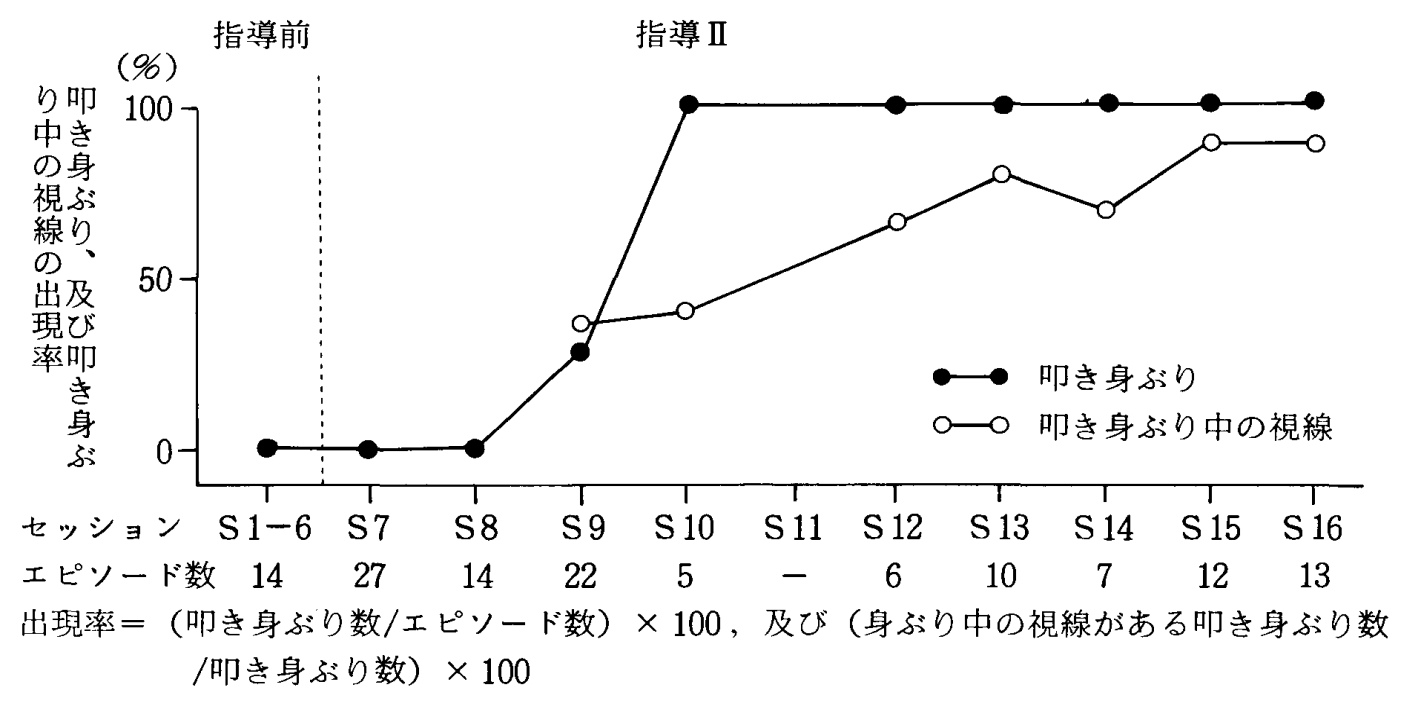

Fig. 2 単一事物場面の各交涉エピソード第一ターンにおける吒き 身ぶりの出現率, 及び吒き身ぶり中の大人への視線の出現率 の時期的な変化 
きをT児はすぐ模倣し (Table 2)、S9 から自発的に使 い始めた。S10 以後の 53 の第一ターンすべてに吒きが 含まれていた（Fig. 2）が、吒きだけの場合は 33\%で、 67\%は叨いた後に続けて合掌するというものであっ た。また第一ターンが合掌であった場合に大人が「な に」と問うと、第二ターンでは物を吒くという身ぶり の変更が $\mathrm{S} 9$ でみられた。視線についてみると S9では 前のみ及び後のみの方が多かったが、吒き身ぶり中の 視線もみられた。この視線は S12 以降は 48 回の第一 ターンの $83 \%$ みららるようになった。吒きが $\mathrm{S} 10$ か ら 100\%になったのと比べると増加の時期が遅れてい る。

\section{指導 II 複数事物場面}

交渉エピソードの第一ターンのT児の渡しに対して 大人が物を吒いたのは $100 \%$ 、T児の吒きを模做した のは $64 \%$ あ゙あ。指導前に同様の場面は行われていな いが、食卓の調味料や薬缶、釜などから一つを選んで 要求する食事場面では、吒きはみられなかった。この 場面が行われ始めた S9 の 10 回の第一ターンのうち 8 回で吒きがみられ、単一事物場面 S9 の 30 回中 8 回に 比べて出現率が高い (Fig. 3)。S9 で両方の場面が交互 に行われている状況では単一事物場面では合掌、複数 事物場面では吒きという使い分けがみられた。S10 以 後は両場面で特に差がない。第一ターンで合掌の場合 に大人が「どれ」と問うと物を吒くという身ぶりの変 更がS11 でみられた。S10 以降に吒きのみられた 76 回 の第一ターンのうち、吒きのみの場合は $49 \%$ 、吒いて

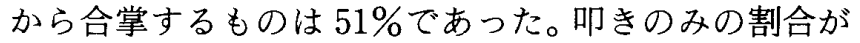
単一事物場面よりも高い。身ぶり中の視線は S10まで は少なく、吒く前にみるか (Table 2) 後にみるかであっ た。S11 以降の 67 回の第一ターンのうち 73\%で身ぶ り中の視線がみられるようになった。視線の出現率が 身ぶりに遅れて高くなる点は単一場面と同じである。

\section{指導 III 遠隔事物場面}

指導前のT肾の合掌 9 回に対して指さしをすること が 3 回、T児の到達 10 回に模倣は 4 回であった。指導 IIIでT览の到達のうち大人が模做したのは $60 \%$ で あった。指導前の遠隔事物場面の第一、第二ターン 22 回で到達は 10 回であったが、指導IIIでは 32 回中 25 回 となっており、指導前より多い。指導前は到達の他は 合掌と手引き、指導IIIでは合掌のみであった。到達が みられたターンで、それのみは $84 \%$ 、合掌をともなう ものは $16 \%$ で単一事物場面と割合が異なる。合掌に対 する大人の言語質問に到達を使う（Table 2) のは指導 前には 6 回中 3 回、指導IIIでは 7 回すべてでみられた。

身ぶり中の視線は指導前には 22 回中 4 回しかなく、 他は身ぶり前か後であった。また指導前の到達 10 回の うち 6 回では、到達と同時に物の方に向かおうとする ことがみられた。そうでない場合は 4 回ともその後に 大人が指さししていたが、到達と同時に移動しようと した場合は大人は指ささなかった。指導IIIでは到達と 同時に移動することはなかった。視線は身ぶり中のも のが 25 回中 13 回で、指導前より多い。T児は大人を みながら到達する場合は、その前に必ず選ぶ物をみて

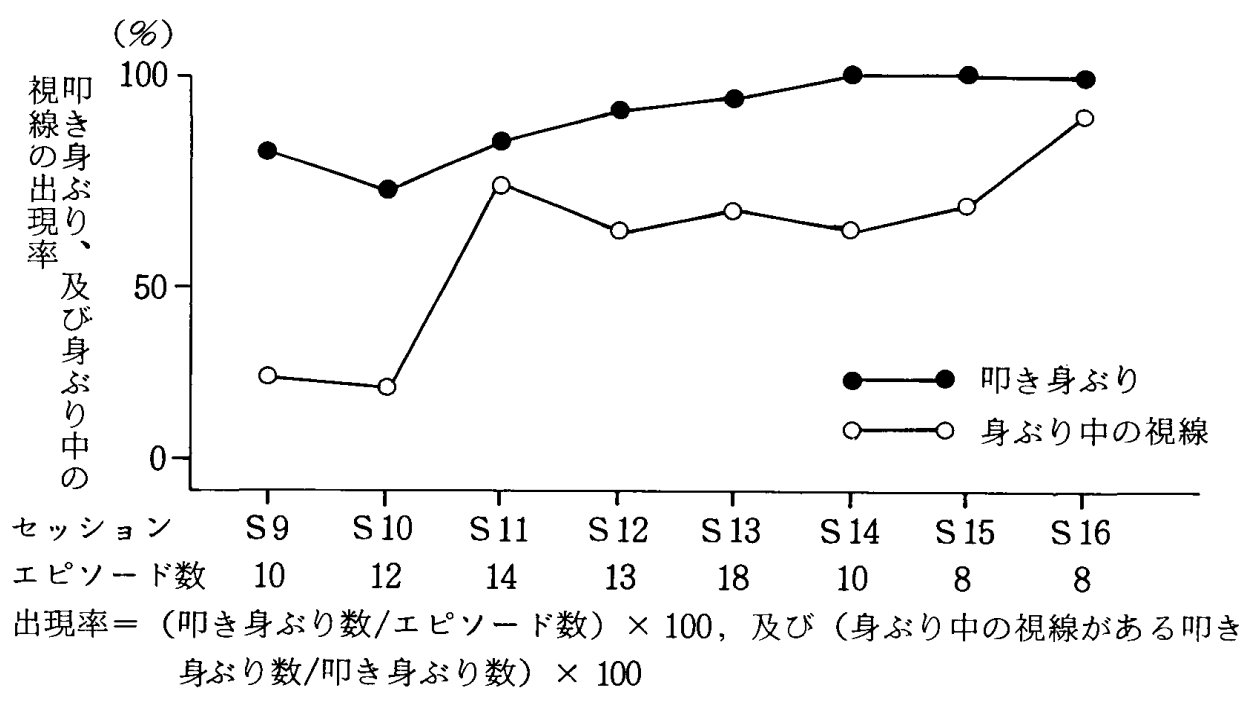

Fig. 3 複数事物場面の各交涉エピソード第一ターンにおける吒き身ぶりの出現 
おり、同一ターンの中で物と大人との見比べが起きて いた。身ぶり中の視線の増加は S19 以後であり、指導 II の 2 つの場面と同じように、身ぶりに比べて出現が 遅れている（Fig. 4)。到達の際に腕の屈曲及び、掌の 垂れ下がりは、指導前にも指導IIIにおいてもみられな かった。

\section{指導 III 退室場面}

指導前、指導III とも大人はほぼすべてのT児の到達 を模做した。到達の出現も指導前に第一、第二ターン 18 回中 11 回、指導IIIでは 10 回中 6 回であまり変化が ない。到達の他は大人にふれるのが 1 回、残りはすべ て合掌であった。到達と合掌の複合はなかった。合掌 への大人の言語質問に到達で答える (Table 2)ことは 指導前は 2 回、指導IIIでは 3 回みられた。身ぶり中の 視線は指導前に 11 回中 5 回で、指導IIIでは 6 回中 4 回 と多くなっている。この視線は指導IIIではすべて直前 に出口への視線をともなう、同一ターン内の大人と場 所の見比べとなっていた。指導前は出口をみない場合 が 5 回あった。到達と同時に移動することは指導前も 指導IIIでもまったくなかった。S20 以降は 4 回すべて の到達で身ぶり中の視線がみられた。他の場面と同じ ように身ぶりに比べ視線の出現が遅れている（Fig. 5)。出口をささない腕が屈曲し掌の垂れ下がった到達 が指導前の S7、8で 3 回みられた。それ以降はない。

\section{身ふりの維持と般化}

指導と類似した場面における要求で、大人を見なが らの合掌、吒き、到達は指導後 3 力月間ずっと維持さ

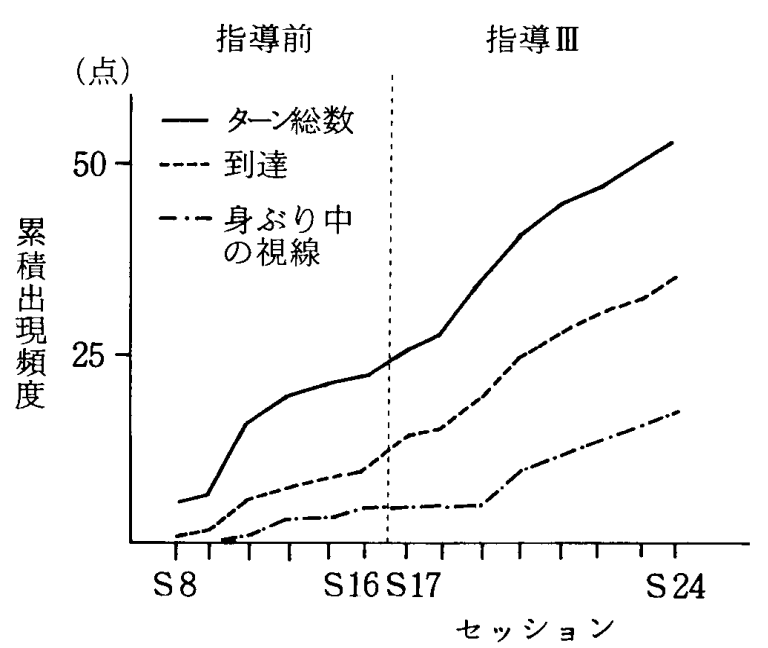

（S.7,9,13はエピソードなし.セッション当たりエピソ 一ド数平均が 3 回以下のため累積出現頻度で示した）

Fig. 4 遠隔事物場面の交涉エピソード第一, 第二ター ンに㧍ける到達, 及び到達身ぶり中の視線の出 現頻度の時期的な変化
れていた。また食事、排泄など指導には含まれていな かった場面へのこれらの般化も確認された。しかし他 の大人への般化は見ながらの合掌に限られた。他の大 人は要求を即時に充足し、 $\mathrm{T}$ 児に要求内容の明確化を 要請しなかった。

\section{その他}

指導 I で大人をみながら合掌するようになった後、 指導IIで大人をみながら吒き、指導IIIで大人をみなが ら到達するようになった後、それぞれの場面で大人は 要求の充足を引き延ばして不規則な交涉を行うように なった。指導 Iでは腕組みで拒否を示して別の大人に 要求するように促し、指導 II 複数事物場面ではT坚が 吒いた物とは異なる物を吒いてみせたり、腕組で拒否 したりした。T児はこれらの不規則な交渉に参加した。 指導 I では何度も合掌したり、別の大人に合掌したり した。指導IIでは自分が吒いた物をまた吒いたり、拒 否されると別の物を吒いたりした。指導III遠隔事物場 面では T览が到達で示した物を大人が拒否すると、 $\mathrm{T}$ 児は到達の方向を変えたり、要求を強調するため手を 振ったりして応じた。指導 II 単一事物場面と指導III退 室場面では特に不規則な交涉はみられなかった。

拒否を示す腕組みの使用は目標には含まれていな かったが、指導 I の後 T児が大人の命令に対して拒否 するのに用いるようになった。T児の身ぶりに音声が ともなう場合が若干あったが、場面による違いはな かった。最後に、T览は指導前は合掌を無表情に行っ ていたが、指導が進むにつれて笑いながら身ぶりをす ることが頻繁にみられるようになり、吒き、到達につ いても同様であった。

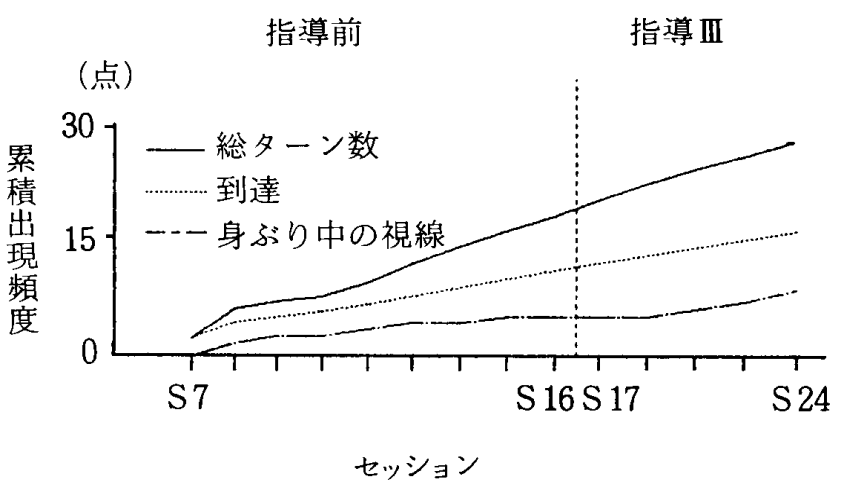

（S 12,18,21,22 はエピソードなし.セッション当たりエ ピソード数平均が 1.2 回のため累積出現頻度で示した)

Fig. 5 退室場面の交涉エピソード第一, 第二ターンに おける到達, 及び到達中の視線の出現頻度の時 期的な変化 


\section{大人との交涉を通じた重度精神遅滞児の前言語的要求伝達の改善}

\section{IV. 考 察}

得られた結果は要求意図を表示する子供の身ぶりを 大人が模倣することが、重度遅滞児との交涉を成立さ せるのに有効であり、その上で要求対象を示す身ぶり のモデルを提供し、それが自発的に使われた際に再度 模做することが前言語伝達技能の改善に有効であるこ とを示している。

指導前にはT児は大人をみながら合掌せず、交涉の 機会は乏しかった。少数の身ぶり後の視線はその潜在 的な機会ではあったが、大人はそれを活用しなかった。 すぐに要求を満たす場合は交涉は起きず、「なに」など の言語応答は交渉を行き詰まらせるだけであった。こ の失敗には $2 つ の$ 要素がある。1つは言語応答が受信 を認めるには有効でなかったこと、もう1つは「なに」 という確認要請に対してT児が明確化できなかったこ とである。これに対し合掌模倣は T览の要求意図の表 現を大人が受信したことを認め、理解を示し要求の充 足を予告するのに成功した。T览は合掌が模倣される かどうかをみるようになり、ここに子供の要求意図の 表現から大人による承認を経て充足にいたるという最 小限の交涉が成立した。

しかし大人による合掌模做は明確化の失敗を修正 (repair)する役割はもたない。T児の合掌は要求意図 を示すのみで、要求対象は示していない。これを示す ことは明確化の有力な方法であるが、それには T児の 身ぶり変更が必要となる。指導 II 及び指導IIIに扔ける 交涉は、指導 I で成立した最小限の交渉を発展させ、 明確化を要請し身ぶりの変更を促すと同時にそのモデ ルを示すものである。その結果下児は吒きや到達を自 発的に使い始めたが、最初は大人を見ながらそれらの 身ぶりをしなかった。これは指導 I 前の合掌と同じで ある。再びここでも大人による身ぶり模倣が重要な役 割を果たした。大人の吒き模倣または到達模做が受信 と意図の理解を示し充足を予告することに成功した。 T児は大人と物を見比べながら吒き、到達するように なり、大人との新たな交涉が展開されるに至った。

こうした変化は単に大人から誘発されて使える伝達 手段が増えたということではなく、T児が要求の意図 と対象を効果的に大人に伝える技能を獲得し、それを 交涉の中で使えるようになったということを意味す る。合掌に対して「なに」と聞かれても身ぶりを変更 するようになったこと、事物が届くところにある指導 IIでは叮き身ぶりと合掌を複合して使うことが多かっ たこと、事物や場所が届くところにない指導IIIでは、
合掌で大人の注意を引き、到達で明確化するという交 涉が多かったこと、不規則な交渉に参加し行き詰まる ことなく要求を伝えるまで努力できたことなどは、そ の現れである。

T児の使ってた合掌身ぶりはチョウダイ身ぶりの一 種である。チョウダイ身ぶりは音声言語を持たない障 害児にはよく教えられているが、それに比べて物のつ つきや吒き、到達、指さしなどの指示身ぶりを使うよ うに子供に求めることは少ないようである。チョウダ イ身ぶりは本来事物要求に適したものであるが、行為 や認可の要求にも転用される。これが使えるようにな ると、多くの場合大人はそれ以上の身ぶりの拡大を求 めようとしないらしい。T児が合掌身ぶりを数年間 使ってきたにもかかわらず、そしてまた到達やつつき がわずかにみられたにもかかわらず、それらを要求に ほとんど使わなかったのは、その使い方を教えられて こなかったためである可能性が高い。言語による明確 化の試みは常に失敗し、結局T児が合掌を繰り返せば 充足するという儀式化した対応がとられ続けてきたと 思われる。T児の伝達技能が認知能力の水準に比べて 低いことは、交渉が成立せず伝達技能を学ぶ機会を得 られなかったためと考えられる。こうした伝達環境は 指導には係わっていない大人との間では依然として続 いている。

もっとも大人は指示身ぶりをまったく教えようとし なかったわけではない。指導前の退室の認可要求にお いてみられた到達は、大人の指さしの模做と思われる。 しかしそれは腕が㐿曲し出口とは異なる方向をさして いた。T児は指示としてこれを学ばなかった可能性が ある。遠隔事物場面では始めから事物に向かって手を 伸ばしていたからである。これは到達しながら歩き始 めるというように伝達性に乏しく、対物的な志向性の 方が強かった。交涉を通じて退室場面では腕を伸ばす という指示性が、遠隔事物場面では大人をみるという 伝達性が明確になった。

本研究は重度精神遅滞児の前言語伝達技能の改善を 目標とするコミュニケーション・アプローチの中で、 具体的な提案が不足していた大人の交涉の仕方につい て、子供の身ぶり模做と身ぶりモデル提供という技法 が有効であることを示した。今後の課題は第一に類似 例についての追試がある。事例は指示身ぶりの前提と なる水準まで認知が達しているものでなければならな い。他の事例の指導にかんする非公式な観察では、同 じような交涉の成立、身ぶりの拡大が確認されている。 なお T児が弱視であったことは指導の時点ではほとん 
ぞ結果には影響していないと思われる。しかし認知と 伝達のずれは、年少時の身ぶりの発達に弱視が影響し た結果である可能性も考慮しなくてはならない。第二 の課題は指導と研究の計画の調整である。吒きのモデ ルの提供は複数事物場面の方が自然で、T児の使用も 早く達成されたので、単一事物場面がいるかどうか検 討が心要である。次にベースラインは指導 III遠隔事物 場面、退室場面では不十分であった。指導 I、IIで身 ぶり模倣が交渉に有効であることを体験した大人が、 IIIの指導前に自然に身ぶりを模倣し始めたためであ る。すべての場面について指導全体の前に同時平行で ベースラインをとる必要がある。指導の順序はII、III がIに先行すると交涉に至らず、誘発されて使えるよ うになるだけで終わる危険性がある。しかしI、III、 IIIを同時に行う可能性は検討されるべきである。般化 の制限は伝達環境の適切化という観点から検討する必 要がある。三番目の課題は模倣とモデル提供という技 法が、慣習化されていない直接的な身ぶりや子供に特 異な身ぶりにかんしても適用できるかどうかを検討す ることである。最後に、非障害児の前言語伝達の発達 との比較がある。T児に抢いて有効であった交涉の技 法は、非障害児との交涉において利用されているのか、 それとも別の手続きで交涉が可能なのか、さらに でみられた変化は生後一年目後半の発達と等価とみな せるのか、合掌と吒きの複合などは重度遅滞児に特有 な発達を示唆するのかなどの問題が残っている。

\section{謝 辞}

研究の実施においてご協力くださった岩本直子、張 田俊美、岩崎佐保子の各氏に感謝する。また本研究は 文部省科学研究費 (一般研究C, 課題番号 02801034) の補助を受けた。

\section{文 献}

1) Bates, E. (1979): The emergence of symbols : Cognition and communication in infancy. Academic Press. New York.

2) Bruner, J. S., Roy, C., and Ratner, L. (1982): The beginnings of request. in K. E. Nelson(Ed.), Children's Language, vol 3. Lawrence Erlbaum.

3) Bruner, J. S (1983) : Child's talk. Oxford University Press.

4) Coupe, J and Goldbart, J. (1988) : Communication before speech. Croom Helm, London.

5) Golinkoff, R. M (1986) : 'I beg your pardon?' The preverbal negotiation of failed messages. Jounal of Child Language, 13, 455-476.

6) 後藤 守 (1976)：母子言語関係の成立過程にかん する研究 (I ) 一ダウン症候群の幼児と母親の 言語関係の分析を中心として一. 北海道教育大 学紀要, c, 26, 2, 9-21.

7) INREAL/outreach (1983): INter-REActive Learning Strategies for Childern. インリアル・ ワークショップ（1985 年大阪）資料.

8) Jones, O. H. M. (1977) : Mother child communication with prelingustic Down's syndrome and normal infants In Schaffer, H.(Ed.), Studies in Mother-Infants Interaction. Academic Press, New York.

9) 木下孝司 (1987): 乳幼児における要求伝達手段の 調整過程一聞き手からのフィードバックとの関 連で一. 教育心理学研究, 35, 351-356.

10) Labato, D., Barrera, R. D., and Feldeman, R. S. (1981): Sensorimotor functioning and prelinguistic communication of severely and profoundly retarded individuals. American Journal of Mental Deficiency, 85, 5, 489-496.

11) McLean, J.E., McLean, L. K. S., Brady, N.C., and Etter, R. (1991): Communication profiles of two types of gesture using nonverbal persons with severe to profound mental retardation. Journal of Speech and Hearing Research, 34, 294 -308 .

12）松尾久枝・加藤孝正 (1989)：重度精神遅滞児の母 子交涉場面における Maternal Speech一前言語 期の健常児との比較一. 特殊教育学研究, $27(1)$, 11-20.

13) Miller, J.E., Chapman, R.S., Branton, M.B., and Reichle, J. (1980) : Language comprehension in sensorimotor stage V and VI. Journal of Speech and Hearing Research, 23, 284-311.

14）長崎 勤・池田由紀江 (1982)：発達遅滞乳幼児に おける前言語的活動一ダウン症乳幼児と正常乳 幼児の要求場面での伝達行為の分析一. 発達障 害研究, 4, 34-43.

15) 大井 学 (1990)：コミュニケーション障害児への 語用論的アプローチについて. 日本特殊教育学 会 28 回大会シンポジウム「ことばの遅れに対す るインリアル指導をめぐって」資料.

16) 大井 学：障害児との会話における大人の応答の 
語用論的な分析. 平沢 一教授退官記念論集. 印刷中.

17) Owens, $R$ (1987): The use of language facilitators with residential retarded populations. Topics in Language Disorders, 7, 47-63.

18) Owens, R. (1989): Cognition and language in the mentally retarded population. In M. Beveridge., G. Conti-Ramsden., and Leudar, I. (Eds.), Language and Communication in Mentally Handicapped People. Chapman and Hall, London.

19) Romski, M. A., Sevick, R. A.,Reumann, R., and Pate, J. S. (1989) : Youngsters with moderate or severe mental retardation and severe spoken language impairment I: Extant communicative patterns. Journal of Speech and Hearing Disorders, 54, 366-373.

20) Sternberg, L., McNerney, D., and Pegnatore, L. (1987): Developing primitive signalling behavior of students with profound mental retardation. Mental Retardation, 25, 13-20.

21) Wooton, A. (1989): Specch to and from a severely retarded young Down's syndrome child. In M. Beveridge., G. Corti-Ramsden., and Leuclar, I. (Eds.), Language and Communication in Mentally Hardicapped People. Chapman and Hall, London.

- 1991.8.5. 受稿, 1992.4.25. 受理 一 


\title{
Communication Training of a Pre-linguistic Child with Severe Mental Retardation
}

\author{
Manabu OOI \\ Faculty Education, Kanazawa University \\ (Kanazawa-Shi, 920)
}

\begin{abstract}
Natural communication methods with adult subjects using gestural monitoring and modelling were used in a therapeutic intervention with a nine year old pre-linguistic child with severe mental retardation. Gestural monitoring occurs when an adult imitates the spontaneous gestural behaviour of the child by responding to requests. Modelling is used to shape more complex and elicited gestural behaviour. It was hypothesized that these strategies would significantly influence communication between adult and child, and increase the frequency of the child's complex gestures.

In phase one of the study, a pressing of hands gesture was imitated. In phase two, the adult responded to this gesture by touching the object requested. Finally, the adult response involved pointing to an out-of reach object. In the latter two phases, both spontaneous and elicited touching and reaching were imitated.

Results demonstrate a low rate of successful negotiations between adult and child underlies communication failure. Prior to intervention, immediate adult response to gesture, or verbal demands to specify target objects or actions was observed. Following intervention, the child visually attended while using the "pressing hands" gesture, began to use touch or reach for objects while looking, and to respond to questions asking for details of the target object by touch or reaching gestures. The findings support the hypothesis that adult gestural monitoring and modelling have a positive effect on communication and the complex gestural behaviour of a pre-linguistic severely mentally retarded child.
\end{abstract}

Key Words : Severe mental retardation, prelinguistic communication, gesture 